\title{
Energy and Sustainability in Museums. The Plant Refurbishment of the Medieval Building of Palagio di Parte Guelfa in Florence
}

\author{
Carla Balocco ${ }^{*}$, Enrico Marmonti \\ Dipartimento di Energetica, Università degli Studi di Firenze, Firenze, Italy \\ Email: *carla.balocco@unifi.it
}

Received September 25, 2012; revised October 23, 2012; accepted November 26, 2012

\begin{abstract}
This paper presents a performance-based design of a HVAC plant and controller system of the "Palagio di Parte Guelfa" Palace, a medieval building converted into a museum in the city of Firenze. Transient simulations to evaluate the internal microclimate conditions during the year for the building and the different system plant were carried out. A comparison between the indoor microclimatic parameters obtained and the values suggested by the standards on protection and conservation of historical works of art, suggested a non-invasive and reversible plant system solution. The Museum of Historical Football building portion is the case study. The proposed plant, a constant air flow system coupled with radiant panels dry mounted above the existing flooring, was simulated throughout the year under transient conditions to evaluate its energy performance. This solution ensures indoor temperature and humidity values suitable for the conservation of works of art and visitor comfort. It is an example of a possible course of action for a plant refurbishment in a historic building converted into a museum, located in climatic regions characterized by high thermal and solar loads. The present paper concerns the study of an integrated and reversible architectural-plant solution proposed: reversibility of the proposed system is understood as the possibility for the present conditions being easily restored.
\end{abstract}

Keywords: Energy Efficiency; Retrofit Solution; Conservation; Museum; Reversible Plant Systems

\section{Introduction}

In Italy there are few buildings specifically designed to contain a museum. Some historical examples such as the Uffizi Gallery, Villa Borghese and some rooms of the Vatican Museums, in addition to a few museum buildings realized from the mid of $20^{\text {th }}$ century, could be mentioned. In the rest of Europe, and mainly in the United States, specific architectural standards for museums are fundamental for any intervention of new design and/or building-plant refurbishment. The exhibition spaces are designed for different services that a museum must offer: conservation, representation, study-research and experimentation, administration, public spaces and people movement. In all these cases a museum building is not only a container for its works of art but becomes itself part of the exhibition. In Italy most of the great museums are located in historical buildings (palaces, residences and villas, religious complexes, etc.) and therefore are subject to cultural heritage rules, to safeguard their identity and historical shape. These museums are located thus: $27 \%$ in homes and palaces, $30 \%$ in churches and monasteries, $20 \%$ in fortresses and castles, $10 \%$ are excavation

${ }^{*}$ Corresponding author. sites or archaeological-classical parks. Buildings previously designed and built for different purposes, for their historical relevance and works of art contained, often become museums. This can produce important changes of the internal room distribution, to satisfy requirements and standard specifications for the safety of visitors or exhibition. Often these rooms are subjected to an elevated numbers of visitors. These circumstances impose, for the museum management, several conditions that must be taken into account: the difficulty and/or inability to insert lifts, the lack of space for plants and laboratories or services and for deposits.

A great deal of the literature shows that, in case of energy refurbishment in historical buildings, for a correct evaluation of the intervention a detailed knowledge of the thermophysical behaviour of the building [1] is necessary. In Italy multidisciplinary contributions, provided by restorers and plant designers, try to work out a proper methodology $[2,3]$.

The indoor microclimate for cultural heritage control is important, because it directly affects the conservation of works of art. The principal agents that cause degradation processes could be various: electromagnetic radiation (light sources, natural and/or artificial), thermo-hy- 
grometric conditions, quality of the air in contact with the work of art. These factors determine three degradation mechanisms: physical (with variation of the shape and size of the objects), chemical (with chemical reactions), biological (with proliferation of microorganisms or fungi). In particular, attention must be paid to the microclimate to prevent condensation on cold surfaces (with formation of fungus and mildew), the blackening of surfaces, or prevent fast stress involving materials due to deformations. As a matter of fact, many materials contained in a historical building, or that also constitute the building envelope, respond to temperature ( $\mathrm{T}$ ) and relative humidity $(\mathrm{RH})$ variations. Organic materials such as wood, paper, parchment or fabrics are the most vulnerable to this changing because they are in equilibrium, in their water content, with the humidity of the surrounding air. Variations of RH or $\mathrm{T}$ in the air produce variation in the materials to seek a new equilibrium, and cause dimensional variations that over time can compromise the integrity of the work of art [4]. To ensure the conservation of works of art it is possible to design a "conservative conditioning" of the building with a continuous control of the T and RH throughout the year, to mitigate the daily and seasonal variations of the internal values of the air temperature and relative humidity. This solution allows control of the indoor conditions to ensure mainly the preservation condition for the work of art during the day and consequently the occupants/visitors comfort especially during the open hours of the museum. Recent studies concerning historical building and museum refurbishment were carried out to evaluate the internal conditions during the operation of air systems [5], and for an non-invasive and integrated allocation of plant equipment with building structures [6].

In this paper the thermophysical behaviour of the "Palagio di Parte Guelfa" Palace in Florence, a very complex architectural structure with different destination (each corresponding to a different thermal zones), was analyzed. The study starts with transient simulations, carried out by a commercial software [7], that were performed for the analysis of the thermo-physical and energy performances of the existing building. Then the integration with the existing plant system was studied and simulated during all the year. A modification of the existing plant, to obtain lower energy consumption and its energy efficiency improvement and at the same time to guarantee optimal thermal conditions, was studied. Transient simulation results showed that the above objectives should not have been obtained only by these modifications. This was the reason because a new plant solution was designed and simulated. A new plant system solution was evaluated taking into account its feasibility and correct allocation in the building thermal zones. The new plant simulation results show that our proposed solution allows guaranteeing microclimatic conditions necessary for the conservation of works of art and at the same time the visitors and occupants comfort. The proposed plant solution is an example of a minimally invasive, easily removable and maintainable plant design for historical buildings especially when the space for plants allocation is minimum and it must be totally compatible with the building structure and its uses.

The results also show that our proposed solution allows guaranteeing microclimatic conditions necessary for the conservation of works of art and at the same time the comfort of visitors and occupants. The proposed plant design is an example of how it can be possible to cover building energy conditioning need, due to the museum but also prestige utilization such as for public meetings and exhibitions, with attention to the energy saving and rational use of energy.

\section{The "Palagio di Parte Guelfa" Palace}

\subsection{Historical Background}

The "Palagio di Parte Guelfa" complex originally consisting of three different buildings, each with important functions and independent, assembled as now visible only from the $16^{\text {th }}$ century (Figure 1). The first core was the "Palazzo di Parte Guelfa", the NE portion of the building. It was the representative institution of the oligarchy during the Republic period. This centre of judiciary authority had a strong control on political life in Florence until the rise to power of the Medici family. The building occupied a strategic position in the city centre of Florence thanks to its proximity to bridges on the Arno river, where trade and manufacturing activities developed. Between 1345 and 1377 the different buildings, such as San Biagio Church, Art Silk laboratories and building blocks with different use, were joined and connected together to expand the judiciary building. A second intervention in the early $15^{\text {th }}$ century was realized. In 1434 the Medici family domination began, which led up to the

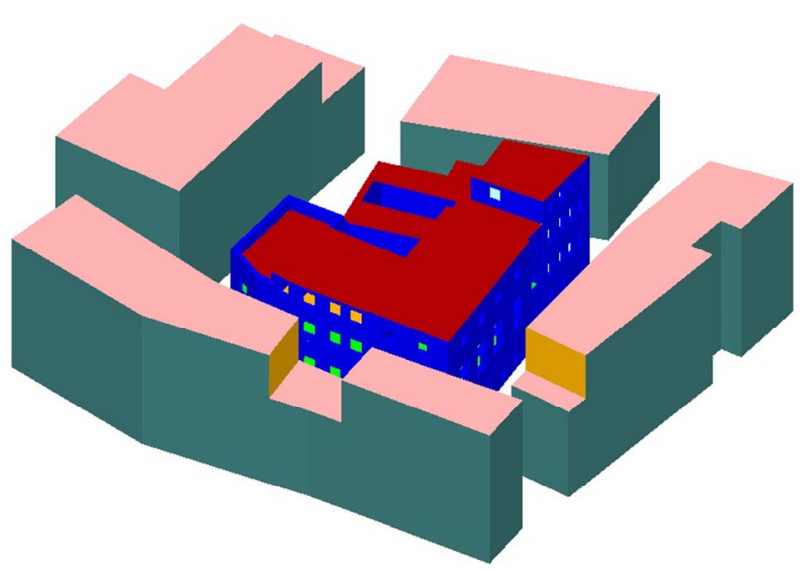

Figure 1. The building studied and the urban context. 
decline of the magistracy of the Guelph Party. It was not abolished, but strongly hampered. In 1430, despite the depletion of its financial assets, the Guelph Party undertook extension work, where Brunelleschi took part in the direction of the constructions before 1434. With an interruption from 1438 to 1442 , a union of different spaces and the Great Hall (actually Brunelleschi Hall) was realized. In the $16^{\text {th }}$ Century Firenze became the capital of the Grand Duchy of Tuscany, with various urban and architectural interventions. After the flood of 1557, Giorgio Vasari intervened on the "Palagio di Parte Guelfa" adjusting and adapting the complex to receive the "Monte Comune" an historical pawnshop and several offices. In 1770 a new intervention adapted the complex to the new situation. The result was a complete distortion of the inner room and space distribution; the building lost its original configuration. A first series of interventions in 1800 aimed to recover the original features of the building complex, connecting the church of San Biagio to ancient Silk weaves guild, creating the conditions for the creation, in the next century, of the Palagio Library. Earlier in the $20^{\text {th }}$ Century, in 1921 , a complete restoration aimed to recover the alterations that had occurred in the past. Starting from historical documents, with the demolition of the building elements such as partitions, stairs, floors added in $16^{\text {th }}$ and $18^{\text {th }}$ Centuries, the Brunelleschi Hall and other historical halls recovered their original size. Each architectural element, was restored or even replaced: all the windows and doors were rearranged in their shape, size and position replacing the old window frames and glazing. Before World War II the complex was restored after air bomb damage.

\subsection{Architectural Features}

At present the historical Palace of "Palagio di parte Guelfa" is located in the city centre of Florence. The building analyzed, isolated respect with to the other surrounding buildings, is divided into different compartments: library, offices, city police and historical football headquarters. A central courtyard, double volume halls, different floor levels are present. Particularly in the north-west annex, the library is composed of a single volume reading room, offices and other service rooms, from the ground to second floor. On the ground floor there is a city police station. The first floor is subdivided between the Historical Football Headquarters, with its double volume halls (Brunelleschi Hall and Fireplace Hall, $12 \mathrm{~m}$ height) and single volume (Captain Hall and Drapes Hall $6.5 \mathrm{~m}$ height), municipality offices and library. At second and third floor other municipality offices are located. Tables 1 and $\mathbf{2}$ show respectively the dimensions of the whole building and the different building zones:
Different building components and different thermophysical properties of materials can be found, due to many and various restorations that took place over the centuries (Table 3). The value of the thermal transmittance of different building components (Table 3) was calculated as suggested by [8].

Windows are composed of a single glazing pane with wood frames. On the ground floor, iron grates provides a partial shading, while on the second floor, on the library roof, a full-length window, without shading, is present. Thermophysical parameters of the transparent materials are shown in Table 4.

\section{Thermal Analysis and Indoor Climate}

\subsection{The Solid and Numerical Model}

Starting from geometrical and construction characteris tics of the building, taking into account the dimensions of each single zone and its architectural features, a solid model was realized with [7]. The geographical location of the building, climatic data and morphology of the surrounding urban context were considered for the evaluation of the solar radiation and projected shadow distribu tion during the year.

Hourly weather data of Florence, from [9], were used. Thermophysical behaviour of the building, uncondi-

Table 1. "Palagio di Parte Guelfa” palace dimensions.

\begin{tabular}{ccc}
\hline & $\begin{array}{c}\text { Height from ground } \\
{[\mathrm{m}]}\end{array}$ & $\begin{array}{c}\text { Height between } \\
\text { stores }[\mathrm{m}]\end{array}$ \\
\hline Ground Floor & 0.0 & 4.5 \\
First Floor & 4.5 & 6.5 \\
Second Floor & 11 & 5.5 \\
Third Floor & 16.5 & 4.2 \\
\hline
\end{tabular}

Table 2. Base area and volume of the different thermal zones.

\begin{tabular}{ccc}
\hline & Base area $\left[\mathrm{m}^{2}\right]$ & Volume $\left[\mathrm{m}^{3}\right]$ \\
\hline Library & 513 & 5120 \\
Police Office & 716 & 2924 \\
Offices First Floor & 66 & 377 \\
Offices Second Floor & 660 & 3378 \\
Offices Third Floor & 160 & 643 \\
Brunelleschi Hall & 622 & 3112 \\
Captains Hall & 69 & 390 \\
Banner Hall & 80 & 453 \\
Fireplace Hall & 135 & 863 \\
\hline
\end{tabular}


Table 3. Thermo-physical properties of building components.

\begin{tabular}{|c|c|c|c|c|c|c|c|c|}
\hline & Layers & width [m] & $\begin{array}{c}\text { Thermal } \\
\text { conductivity } \\
{[\mathrm{W} / \mathrm{m} \mathrm{K}]}\end{array}$ & $\begin{array}{l}\text { Density } \\
{\left[\mathrm{Kg} / \mathrm{m}^{3}\right]}\end{array}$ & $\begin{array}{l}\text { Heat capacity } \\
{[\mathrm{J} / \mathrm{kg} \mathrm{K}]}\end{array}$ & $\begin{array}{l}\text { width } \\
\text { [m] }\end{array}$ & $\begin{array}{l}\text { U value } \\
{\left[\mathrm{W} / \mathrm{m}^{2} \mathrm{~K}\right]}\end{array}$ & $\begin{array}{c}\text { Time } \\
\text { Costant }[\mathrm{h}]\end{array}$ \\
\hline \multirow{3}{*}{ Stone wall $0.7 \mathrm{~m}$} & $\begin{array}{l}\text { Internal plastering } \\
\text { (lime and plaster) }\end{array}$ & 0.02 & 0.5 & 1300 & 1000 & \multirow{3}{*}{0.7} & \multirow{3}{*}{2.95} & \multirow{3}{*}{10.1} \\
\hline & Stone & 0.65 & 7.3 & 2500 & 800 & & & \\
\hline & $\begin{array}{r}\text { External plastering } \\
\text { (lime and plaster) }\end{array}$ & 0.02 & 0.5 & 1300 & 1000 & & & \\
\hline \multirow{3}{*}{ Stone wall $0.95 \mathrm{~m}$} & $\begin{array}{l}\text { Internal plastering } \\
\text { (lime and plaster) }\end{array}$ & 0.02 & 0.5 & 1300 & 1000 & \multirow{3}{*}{0.95} & \multirow{3}{*}{2.68} & \multirow{3}{*}{15.6} \\
\hline & Stone & 0.9 & 7.3 & 2500 & 800 & & & \\
\hline & $\begin{array}{l}\text { External plastering } \\
\text { (lime and plaster) }\end{array}$ & 0.02 & 0.5 & 1300 & 1000 & & & \\
\hline \multirow{3}{*}{ Internal wall } & $\begin{array}{l}\text { Internal plastering } \\
\text { (lime and plaster) }\end{array}$ & 0.01 & 0.5 & 1300 & 1000 & \multirow{3}{*}{0.1} & \multirow{3}{*}{2.222} & \multirow{3}{*}{0} \\
\hline & Air brick & 0.08 & 0.4 & 700 & 840 & & & \\
\hline & $\begin{array}{r}\text { External plastering } \\
\text { (lime and plaster) }\end{array}$ & 0.01 & 0.5 & 1300 & 1000 & & & \\
\hline \multirow{4}{*}{ Cross vault } & Terracotta floor & 0.08 & 0.47 & 1600 & 800 & \multirow{4}{*}{0.59} & \multirow{4}{*}{0.801} & \multirow{4}{*}{$>24$} \\
\hline & Mortar footing & 0.03 & 0.18 & 1800 & 800 & & & \\
\hline & Replenishment & 0.4 & 0.7 & 1500 & 1000 & & & \\
\hline & Solid brick board & 0.08 & 0.47 & 1600 & 840 & & & \\
\hline \multirow{3}{*}{ Ground floor } & Solid brick board & 0.08 & 0.47 & 1600 & 840 & \multirow{3}{*}{0.51} & \multirow{3}{*}{0.927} & \multirow{3}{*}{20.5} \\
\hline & Mortar footing & 0.03 & 0.18 & 1800 & 800 & & & \\
\hline & Replenishment & 0.4 & 0.7 & 1500 & 1000 & & & \\
\hline \multirow{3}{*}{ Internal floor } & Solid brick board & 0.08 & 0.47 & 1600 & 840 & \multirow{3}{*}{0.16} & \multirow{3}{*}{1.648} & \multirow{3}{*}{2} \\
\hline & Mortar footing & 0.03 & 0.18 & 1800 & 800 & & & \\
\hline & wood & 0.05 & 0.5 & 500 & 1000 & & & \\
\hline \multirow{3}{*}{ Roof } & wood & 0.05 & 0.5 & 500 & 1000 & \multirow{3}{*}{0.13} & \multirow{3}{*}{2.055} & \multirow{3}{*}{0.72} \\
\hline & Mortar footing & 0.03 & 0.18 & 1800 & 800 & & & \\
\hline & Roof tiles & 0.05 & 1 & 200 & 800 & & & \\
\hline
\end{tabular}

Table 4. Thermo-physical properties of transparent materials.

\begin{tabular}{|c|c|c|c|c|c|c|c|c|c|c|}
\hline & \multirow{2}{*}{$\begin{array}{l}\text { Width } \\
{[\mathrm{m}]}\end{array}$} & \multirow{2}{*}{$\begin{array}{c}\text { Solar } \\
\text { transmittance }\end{array}$} & \multicolumn{2}{|c|}{$\begin{array}{l}\text { External solar } \\
\text { absorbance }\end{array}$} & \multicolumn{2}{|c|}{$\begin{array}{l}\text { Internal solar } \\
\text { absorbance }\end{array}$} & \multirow{2}{*}{$\begin{array}{c}\text { Light } \\
\text { transmittance }\end{array}$} & \multicolumn{2}{|c|}{ Emissivity } & \multirow{2}{*}{$\begin{array}{l}\text { U value } \\
{\left[\mathrm{W} / \mathrm{m}^{2} \mathrm{~K}\right]}\end{array}$} \\
\hline & & & Ext. Surf. & Int. Surf. & Ext. Surf. & Int. Surf. & & $\begin{array}{l}\text { Ext. } \\
\text { Surf. }\end{array}$ & $\begin{array}{l}\text { Int. } \\
\text { Surf. }\end{array}$ & \\
\hline Single layer glass & 0.02 & 0.88 & 0.02 & 0.02 & 0.02 & 0.02 & 0.91 & 0.1 & 0.1 & 5.935 \\
\hline
\end{tabular}

tioned and also with the plant systems in working conditions were simulated in transient conditions for the whole year using [7]. In particular, the energy performances of the system were analyzed for the coldest ( $5^{\text {th }}$ of January) and the hottest day $\left(16^{\text {th }}\right.$ July). The different thermal zones were modelled, considering their different indoor thermo-hygrometric conditions, their utilization and different heating-cooling plant system. Thermal loads due to the occupants, different equipment and lighting sys- tems were considered for each thermal zone (library, offices and the halls of historic football) with respect to their opening time. Different corresponding hourly schedules were defined: for the period from Monday to Friday from 9:00 to 18:00 the zones were considered when open and closed for the weekend (Table 5). The air ventilation rates used for each zone are those suggested [10]; the latent and sensible thermal loads due to the occupants are provided by [11] and for equipment and lighting by [12]. 
The dynamic evaluation of the building thermo physical performance, total heat transferred through the building envelope during the year and total energy consumption of the building-plant system were evaluated using [7]. The numerical model used by [7] is based on the method derived from the ASHRAE Response Factor Technique [13]. This model uses an efficient computational procedure that calculates the heat fluxes through the building component surfaces as function of their temperature evolution and distribution during time. Transient heat transfer, due to heat conduction and heat capacity of each building components, is modelled using the normal coordinate method [14] with a time-step of 1 hour. This approach, closely related to the methods based on the Response Factors and Conduction Transfer Functions [15], provides important run-time saving. Basic related theoretical formulas concerning thermal and in door climate analysis, in particular referred to the evaluation of the indoor air temperature and air specific humidity are provided in the appendix.

\subsection{Existing Plant System}

Plant information and data were provided by technical offices of the municipality. The heating system is composed of a boiler, with total thermal power $245 \mathrm{~kW}$, located on the ground floor. Two different hot water coils, high temperature $\left(70^{\circ} \mathrm{C}\right)$ for radiators and low temperature $\left(50^{\circ} \mathrm{C}\right)$ for fancoils and splitters, are linked to the different types of terminals in each thermal zone.

In the Historical Football Headquarter, including the Brunelleschi Hall, Captains Hall, Drapes Hall, Fireplace Hall, only a fancoil plant is present. During the summer season a chiller placed in the courtyard of the palace, with thermal power $36.6 \mathrm{~kW}$, provides chilled water (temperature $7^{\circ} \mathrm{C}-12^{\circ} \mathrm{C}$ ) for fancoils. A heat pump sys- tem is used for the heating and cooling of all the zones with offices on the second floor.

Italian Standards [16] impose a heating period from November 1 to April 15, up to 12 hours. Therefore, the heating system usually works on weekdays from 7:00 to 19:00. During the weekend this plant does not work. Two different occupancy profiles, were considered: the first referred to opening hours and connected internal thermal gains; the second with a "weekend profile" without internal gains.

\subsection{Existing Plant System: Results and Discussion}

Transient simulations, carried out both for the building unconditioned and that with the existing plant system in working conditions, allow the evaluation of the correct values of indoor air temperature and relative humidity with respect to the recommended limits for protection and conservation of works of art, provided by Italian [17], European [18,19] and US standards [20]. Figure 4 shows the obtained results and the acceptability values range for thermo-hygrometric parameters compared with these standards.

In all the thermal zones studied the indoor temperature trend, provided by transient simulation results of unconditioned building, is between the values of $6^{\circ} \mathrm{C}$ and $36^{\circ} \mathrm{C}$. The hoarded frequency and deviation index, calculated according to [19], for the air temperature and relative humidity were evaluated for all the studied zones. As an example Figures 2 and $\mathbf{3}$ provide respectively the air temperature and air relative humidity frequency distributions and the acceptability values range obtained for the Fireplace Hall.

In these figures it is possible to note how the yearly

Table 5. Thermal loads for the different zones.

\begin{tabular}{|c|c|c|c|c|c|c|c|c|c|}
\hline & Library & $\begin{array}{l}\text { Police } \\
\text { Office }\end{array}$ & $\begin{array}{c}\text { Offices } \\
\text { First Floor }\end{array}$ & $\begin{array}{c}\text { Offices } \\
\text { Second Floor }\end{array}$ & $\begin{array}{c}\text { Offices } \\
\text { Third Floor }\end{array}$ & $\begin{array}{c}\text { Brunelleschi } \\
\text { Hall }\end{array}$ & $\begin{array}{c}\text { Captains } \\
\text { Hall }\end{array}$ & $\begin{array}{c}\text { Banner } \\
\text { Hall }\end{array}$ & $\begin{array}{c}\text { Fireplace } \\
\text { Hall }\end{array}$ \\
\hline Floor Area $\left[\mathrm{m}^{2}\right]$ & 513 & 716 & 66 & 660 & 160 & 622 & 69 & 80 & 135 \\
\hline Occupancy UNI 10339 [pers] & - & 43 & 4 & 40 & 10 & 37 & 4 & 5 & 8 \\
\hline Municipality Occupancy [pers] & 54 & 27 & 9 & 9 & 9 & - & - & - & - \\
\hline Ventilation $\left[{ }^{*} 10^{-3} \mathrm{~m}^{3} / \mathrm{s}\right.$ pers $]$ & 6 & 11 & 11 & 11 & 11 & - & - & - & - \\
\hline Ventilation $\left[{ }^{*} 10^{-3} \mathrm{~m}^{3} / \mathrm{m}^{2} \mathrm{~s}\right]$ & - & - & - & - & - & 1.5 & 1.5 & 1.5 & 1.5 \\
\hline Air fresh rate $[\mathrm{L} / \mathrm{s}]$ & 324 & 297 & 99 & 99 & 99 & 933 & 104 & 120 & 203 \\
\hline Lightning gains $\left[\mathrm{W} / \mathrm{m}^{2}\right]$ & 15 & 15 & 15 & 15 & 15 & 20 & 20 & 20 & 20 \\
\hline Occupancy sensible gain $\left[\mathrm{W} / \mathrm{m}^{2}\right]$ & 8 & 3 & 11 & 1 & 5 & 5 & 5 & 5 & 5 \\
\hline Occupancy latent gain $\left[\mathrm{W} / \mathrm{m}^{2}\right]$ & 3 & 1 & 4 & 0 & 1 & 1.6 & 1.6 & 1.6 & 1.6 \\
\hline Equipment sensible gains $\left[\mathrm{W} / \mathrm{m}^{2}\right]$ & 5.4 & 10.8 & 5.4 & 5.4 & 5.4 & - & - & - & - \\
\hline Equipment latent gains $\left[\mathrm{W} / \mathrm{m}^{2}\right]$ & - & - & - & - & - & - & - & - & - \\
\hline
\end{tabular}




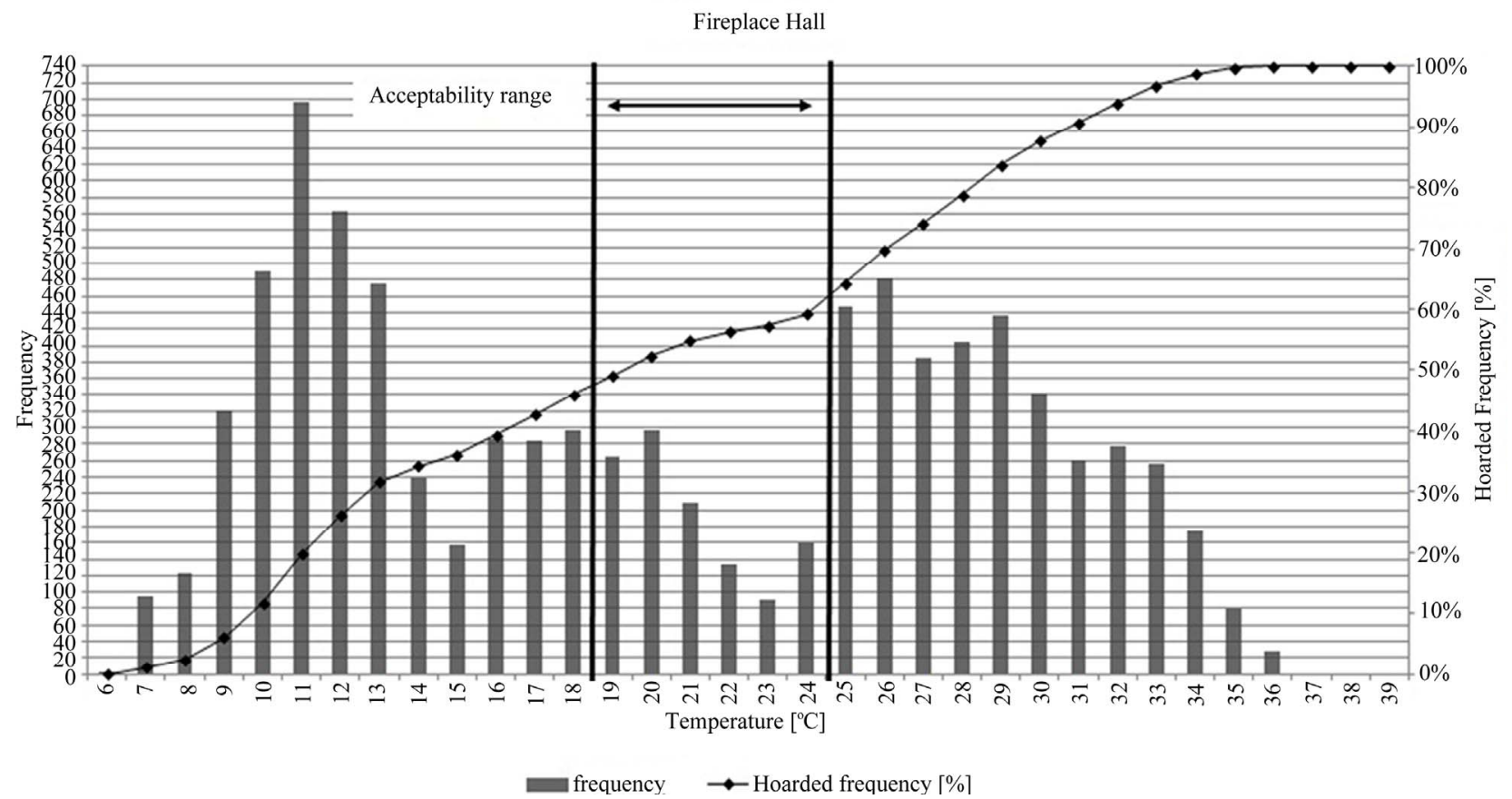

Figure 2. Transient simulation results on the yearly temperature values inside the Fireplace hall.

Fireplace hall

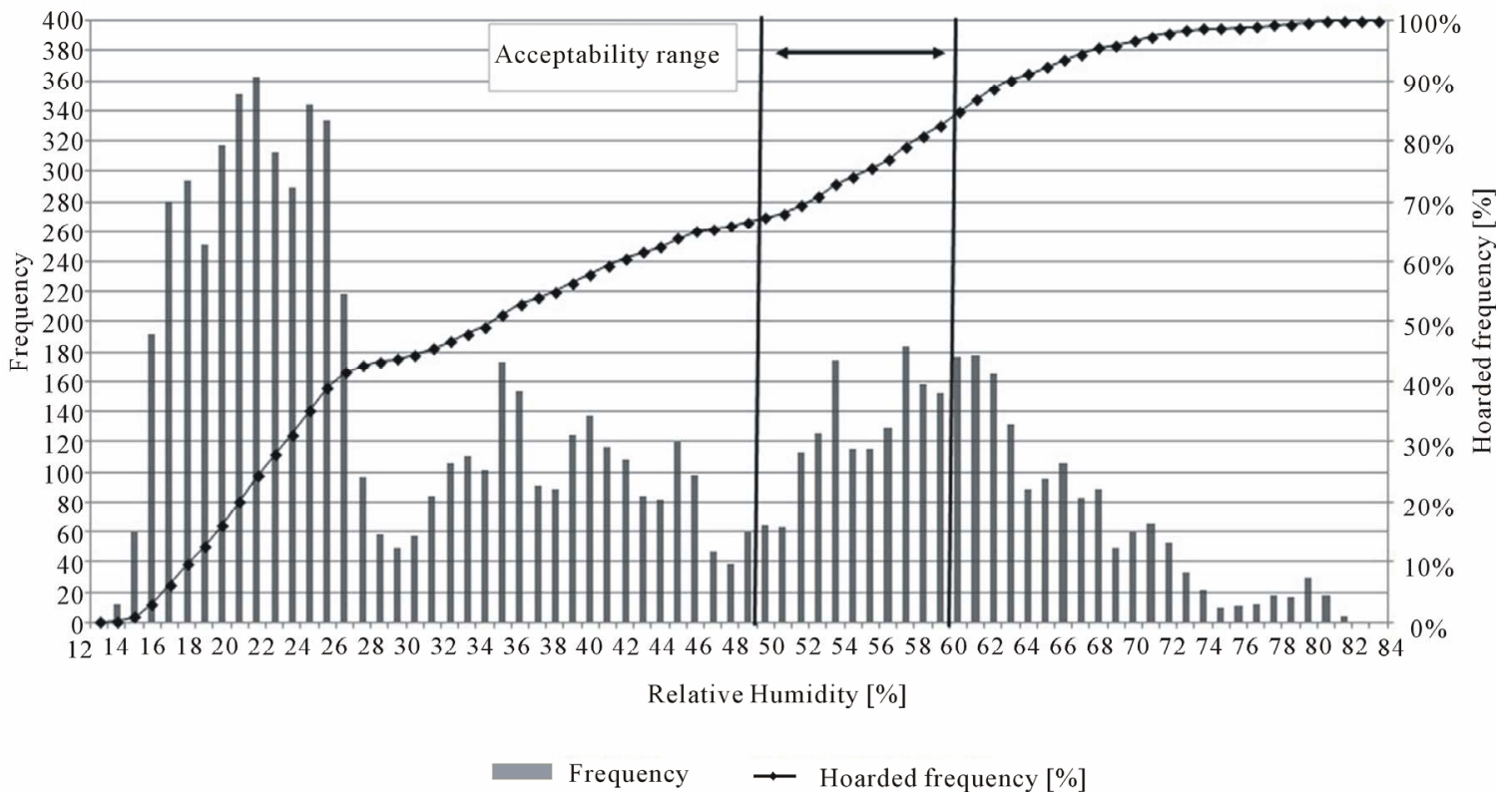

Figure 3. Transient simulation results on the yearly relative humidity values inside the Fireplace Hall.

values obtained without the air-conditioning plant, are very different both for temperature and for relative humidity, with higher frequencies in the lower values. The deviation index compared to the recommended values is $87 \%$ for the air temperature and $73 \%$ for relative humidity.

Considering the existing plant in working conditions and latent and sensible loads due to occupants and visi- tors, further transient simulations for all the zones were carried out. In particular, the system was considered in working conditions from 7:00 to 19:00 in the winter season, and from 8:00 to 18:00 in the summer season. During these hours the existing plant system allows control only for internal temperature values. In the other hours of the day, and especially on weekends when a wide part of the building is closed, the plant system does not provide 
a control on indoor microclimate. Taking into account these condition, simulations were carried out and the obtained results provided deviation index values of $43 \%$ for the air temperature and $66 \%$ for relative humidity.

Before proposing a new plant design, a first hypothesis of maintaining the existing plant with a modification solution of the present control system was evaluated. During the day and weekends, the control system was considered in working condition for $24 \mathrm{hrs}$.

For the above conditions, simulation results show as the air temperature values are maintained within the acceptability range, with a deviation index of $3 \%$. However, this improvement of the existing plant does not allow a control of relative humidity. Figure 5 shows a densification of temperature values around the range of $19^{\circ} \mathrm{C}$ $24^{\circ} \mathrm{C}$ and a scattering of the air relative humidity values outside the acceptability values range. This fact produces a deviation index value of $64 \%$ for relative humidity, that is beyond the standard limits.

\section{The Proposed Plant System}

Technical improvements and applied solutions of the plant systems designed for historical buildings [4,21] suggested a plant refurbishment in order to ensure the air temperature and the relative humidity control with respect to the national and international standards for the preservation, conservation and maintenance of historical works [17-19], as also shown in Table 6.

The Superintendency of Cultural Heritage requirements do not allow modification of the opaque and transparent building components to improve the thermophysical building behaviour. It is also not possible to change the structure of the building, roof, and floor. However, the proposed system plant is a non-invasive and completely removable solution, easy to maintain, based on the use of the existing heating and cooling power plants. The plant solution proposed is based on the concept of reversibility and sustainability. It allows finding out the compromise between energy retrofitting and conservation/ maintenance of the historical building and its architectural features. The existing fancoils plant system was replaced with a constant flow air-conditioning system (CAV) coupled with radiant panels. This implies a designed introduction of each small and compact Air
Treatment Unit (ATU): for the Brunelleschi Hall one ATU is located in the stairs space; in the Fireplace Hall one ATU is near the main door, adjacent to the external ambient, and the return and exhaust air ducts system is located inside the chimney; for the two Halls of Drapes and Captains, two ATU are located on the building roof and the air ducts system uses the present cavedium and chimneys. In Figure 6 the air ducts distribution inside each hall and the ATU location is provided. The CAV system balances the latent loads in the hall and ensure a mechanical ventilation, with a fresh air flow about (Table 5) as suggested in [10]. The radiant panels, dry mounted above the existing floor (their reduced thickness is 2.5 $\mathrm{cm}$ ), ensures the heating and cooling of the hall.

As shown in Figure 7, for each room the integration and allocation of an air circuit with compact air handling units was designed. A double heat recovery system, provided by a cross flow heat-exchanger, with $70 \%$ efficiency [22], on the air coil allows a reduction of the plant energy consumption for the air treatment as suggested [23].

The CAV system provides constant fresh air flow rate, following the values reported in Table 5 for each room during opening hours. A mixing plenum supports air recirculation during the remaining hours. The cooling battery of the CAV system allows air dehumidification with humidity ratio values up to $0.001 \pm 0.0005 \mathrm{~g}_{\mathrm{v}} / \mathrm{kg}_{\mathrm{dry}}$ air. opening hours (from 9 to 18 ) and at $19^{\circ} \mathrm{C} \pm 1{ }^{\circ} \mathrm{C}$ in the remaining hours. After air dehumidification, a pre-heating battery maintains the temperature of the mixed air at $17^{\circ} \mathrm{C} \pm 1^{\circ} \mathrm{C}$. A post heating battery maintains the air temperature value of the inlet air at $22^{\circ} \mathrm{C} \pm 1{ }^{\circ} \mathrm{C}$. In the winter season a humidification system, with control on the extraction circuit of the air, maintains the relative humidity between $50 \%-60 \%$. Then in the winter season radiant panels system contributes to maintaining the indoor air temperature at $20^{\circ} \mathrm{C} \pm 1{ }^{\circ} \mathrm{C}$ during the opening hours (from 9 to 18 ) and at $19^{\circ} \mathrm{C} \pm 1{ }^{\circ} \mathrm{C}$ in the remaining hours. During summer the radiant panels contribute to maintaining the indoor air temperature at $24^{\circ} \mathrm{C} \pm 1{ }^{\circ} \mathrm{C}$ during the hours and at $25^{\circ} \mathrm{C} \pm 1{ }^{\circ} \mathrm{C}$ in the remaining hours.

Table 7 shows the comparison between the air flowrate values of each plant system configurations. The design flow rate of the fancoils plant, for $9-18 \mathrm{hrs}$ and

Table 6. Air temperature and relative humidity values.

\begin{tabular}{|c|c|c|c|c|c|c|c|c|c|}
\hline & & \multicolumn{4}{|c|}{ Vanished wood works } & \multicolumn{4}{|c|}{ Fabrics and tapestries } \\
\hline & & $\theta_{0}\left[{ }^{\circ} \mathrm{C}\right]$ & $\Delta \theta_{\max }\left[{ }^{\circ} \mathrm{C}\right]$ & $u_{0}[\%]$ & $\Delta u_{\max }[\%]$ & $\theta_{0}\left[{ }^{\circ} \mathrm{C}\right]$ & $\Delta \theta_{\max }\left[{ }^{\circ} \mathrm{C}\right]$ & $u_{0}[\%]$ & $\Delta u_{\max }[\%]$ \\
\hline \multicolumn{2}{|c|}{ Italian standards } & $19-24$ & \pm 1.5 & $50-60$ & - & - & - & $40-60$ & - \\
\hline \multicolumn{2}{|c|}{ UNI 10829:1999 } & $19-24$ & \pm 1.5 & $50-60$ & \pm 4 & $19-24$ & \pm 1.5 & $30-50$ & \pm 6 \\
\hline \multirow{2}{*}{ ASHRAE } & $\mathrm{B}$ class protection & $15-25$ & \pm 5 & 50 & \pm 10 & $15-25$ & \pm 5 & 50 & \pm 10 \\
\hline & $\mathrm{C}$ class protection & $15-25$ & $<30$ & $25-75$ & - & $15-25$ & $<30$ & $25-75$ & - \\
\hline
\end{tabular}


$24 \mathrm{hrs}$, was calculated using a temperature difference of $10^{\circ} \mathrm{C}$ for heating and $5^{\circ} \mathrm{C}$ for cooling. The CAV plant system proposed provides an air flow rate considerably lower, but sufficient to control the latent load in the different rooms. The remaining sensible load demand is provided by the radiant panels system. The Brunelles-
chiHall is characterized by a large volume but a lower base area. Thermal loads due to lighting system and occupants/visitors were assessed in terms of $\mathrm{W} / \mathrm{m}^{2}$. In these conditions a lower air flow rate, to compensate the lower latent loads, was required compared to that by the other halls (Table 5). In this hall the radiant panels system

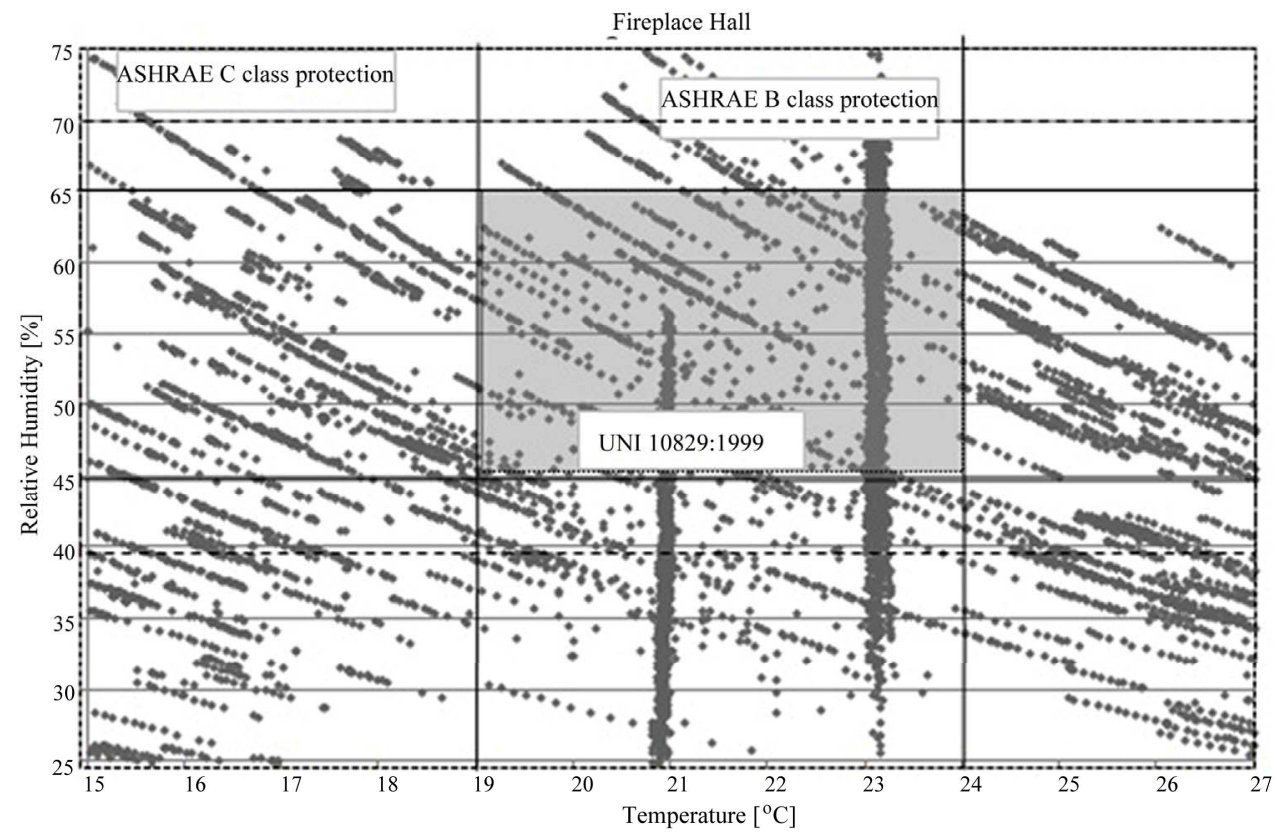

Figure 4. The existing plant system in working conditions: transient simulation results on the yearly temperature and relative humidity values inside the Fireplace Hall and the corresponding acceptability values range.

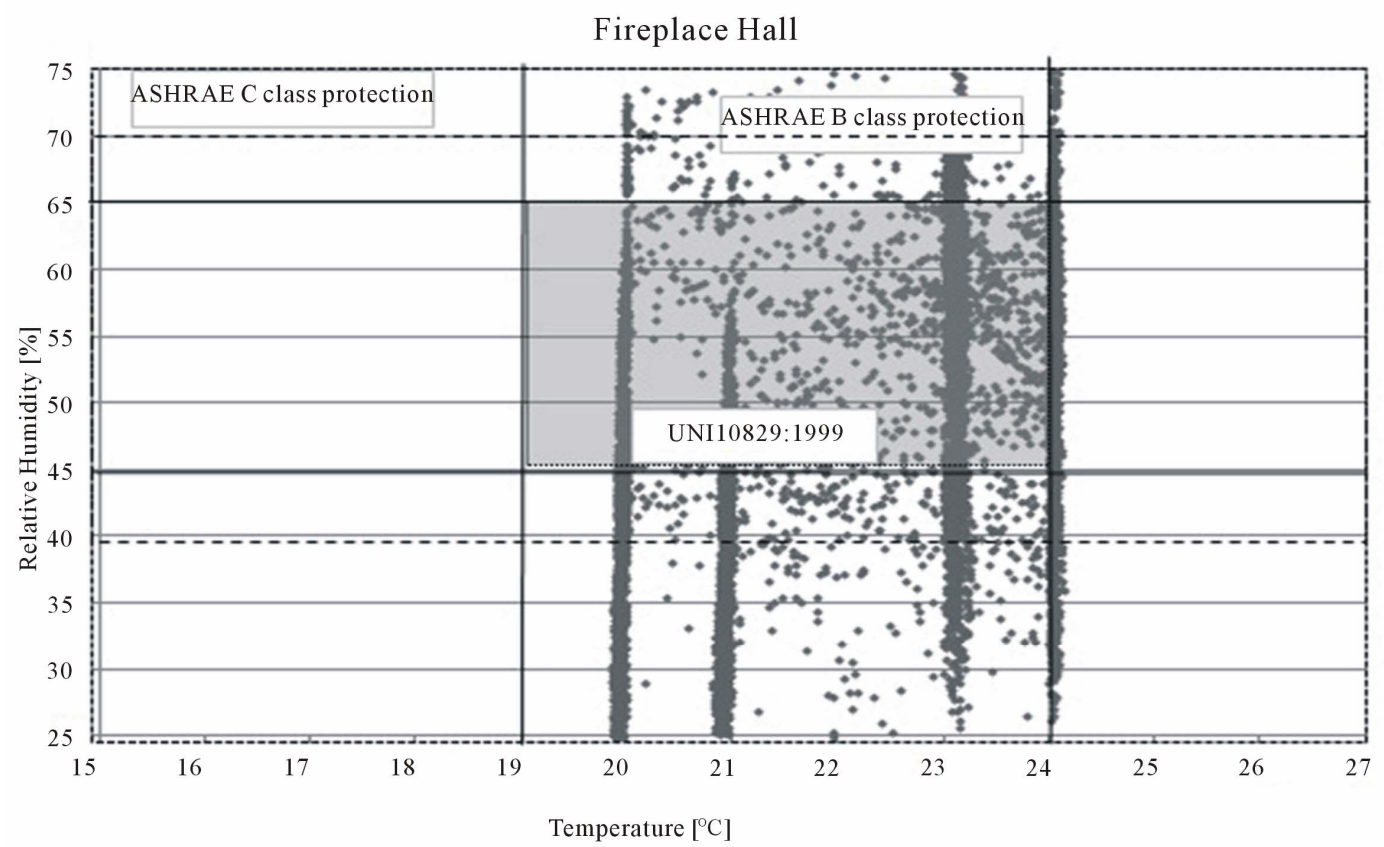

Figure 5. The existing plant system in working conditions with the proposed regulation system for $24 \mathrm{~h}$ working: transient simulation results on the yearly temperature and relative humidity values inside the Fireplace Hall and the corresponding acceptability values range. 


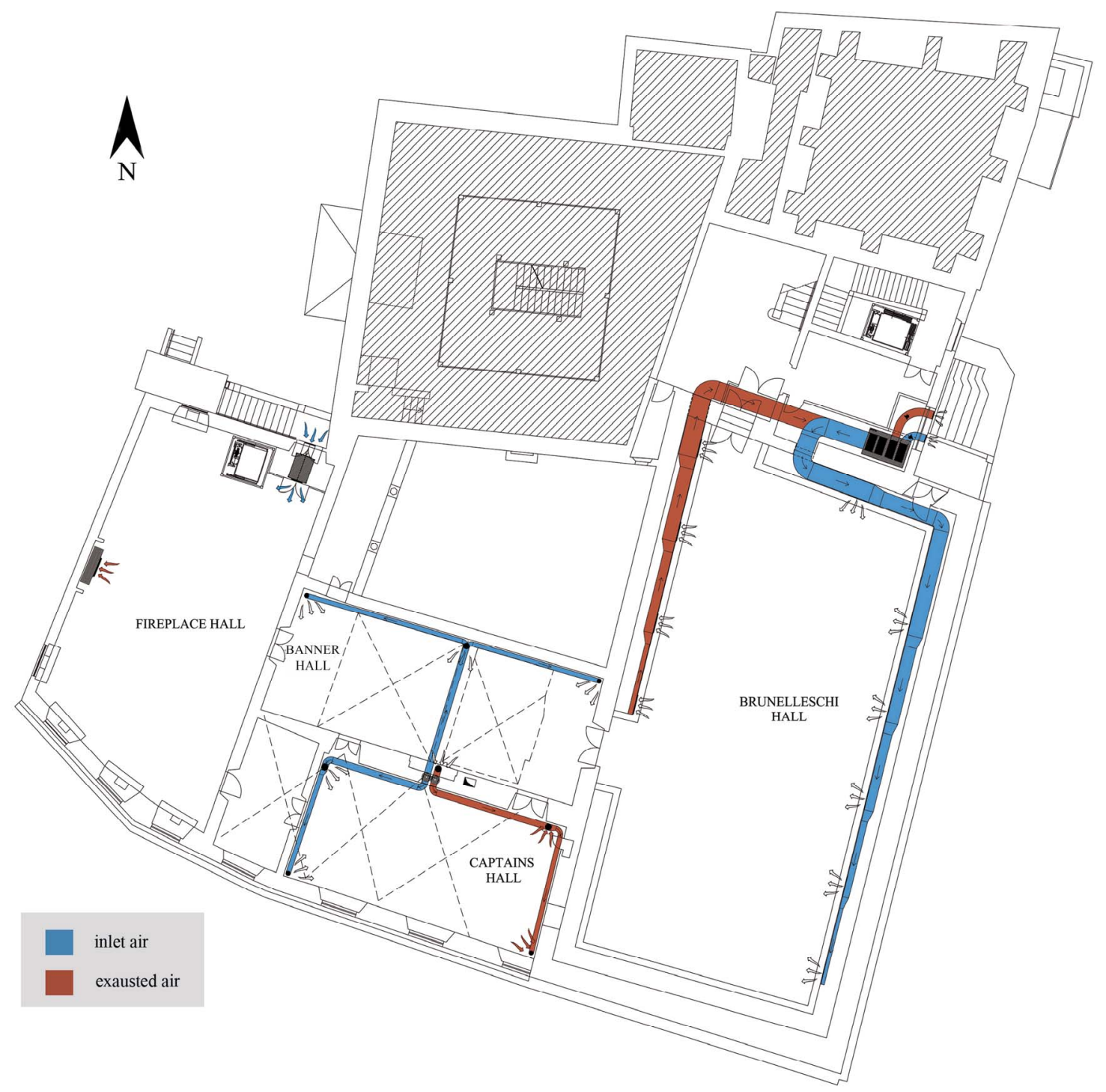

Figure 6. The proposed plant system: HVAC air ducts distribution and allocation in the historical Halls.

Table 7. Hourly air flow rates for the different Halls.

\begin{tabular}{cccc}
\hline & \multicolumn{3}{c}{ Design Air Flow Rate [1/s] } \\
\cline { 2 - 4 } & Existing Plant $9-18$ & Existing Plant 24 hrs & Proposed Plant \\
\hline Brunelleschi Hall & 16,000 & 16,000 & 150 \\
Banner Hall & 1100 & 1100 & 700 \\
Captains Hall & 1250 & 1250 & 650 \\
Fireplace Hall & 2400 & 2400 & 700 \\
\hline
\end{tabular}

provides optimal performances to compensate the remaining sensitive loads, derived from the heat balance of the hall in the summer and winter season.

The plant system proposed allows air temperature and relative humidity values inside the acceptability values range [17-19], with the two corresponding deviation indexes equal to $0 \%$. In Figure 8 results obtained for the
Fireplace Hall are given.

Tables 8 and $\mathbf{9}$ show the thermal loads obtained for the coldest day of the year (January 5), with minimum temperature of $-3.3^{\circ} \mathrm{C}, \mathrm{RH}=82 \%$ and humidity ratio $2.47 \mathrm{~g}_{\mathrm{w}} / \mathrm{kg}_{\text {air dry }}$, and for the hottest day (16 July) of the year with maximum temperature of $38.5^{\circ} \mathrm{C}, \mathrm{RH}=14 \%$ and humidity ratio $5.90 \mathrm{~g}_{\mathrm{w}} / \mathrm{kg}_{\text {air dry. These tables also }}$ 
show, how the thermal loads required for a temperature and relative humidity control in all the rooms are slightly higher than those required by the present fancoils plant system, also considered in the two studied working conditions.

The daily heating and cooling hourly thermal power due to the proposed system plant system is higher for all the conditions and for each different hall analyzed (Tables 8 and 9). These higher values, however comparable, are due to the necessary ventilation and air treatment. In particular, for the Drapes Hall, where a greater ventilation and air treatment is necessary in comparison with the other halls, thermal power required by the CAV system is higher, while power requested by the radiant panels is lower. On the contrary, for the Brunelleschi Hall the higher power required is due to the radiant panels, because the inlet air flow is lower. The proposed plant solution presents lower powers for the heating and cooling season and also for the hottest and coldest days. e.g., Figures $\mathbf{9}$ and $\mathbf{1 0}$ provide these results obtained for the Fireplace Hall.

Hourly powers required for the air treatment (cooling with dehumidification and post-heating) did not exceed 5 $\mathrm{kW}$ and $7 \mathrm{~kW}$ respectively.

As a matter of fact, the same hourly trend of cooling power, due to the proposed plant solution, is present during the hottest day, July 16 (Figure 10). During winter and summer air dehumidification is necessary on many days and this can be noted taking into account both the coldest day (Figure 8) and the hottest day (Figure 9)

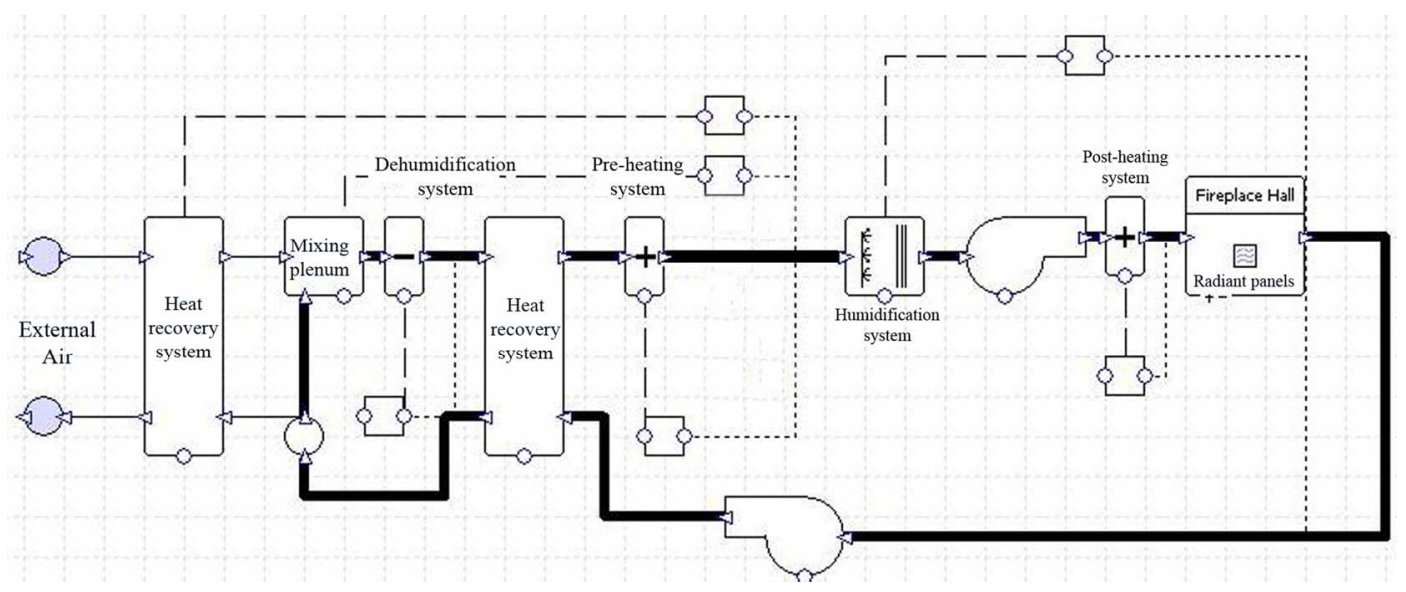

Figure 7. The proposed CAV/radiant panels system-plant scheme.

Table 8. Daily heating power for the different system plants, 5 January.

\begin{tabular}{|c|c|c|c|c|}
\hline \multicolumn{5}{|c|}{$5^{\text {th }}$ January heating power $[\mathrm{kW}]$} \\
\hline & \multirow[t]{2}{*}{ Existing plant } & \multirow{2}{*}{ Fancoil 24 hrs } & \multicolumn{2}{|c|}{ Proposed plant } \\
\hline & & & CAV & Radiant panels \\
\hline Brunelleschi Hall & 417 & 539 & 236 & 624 \\
\hline Banner Hall & 65 & 114 & 207 & 67 \\
\hline Captains Hall & 48 & 141 & 192 & 52 \\
\hline Fireplace Hall & 145 & 416 & 204 & 206 \\
\hline
\end{tabular}

Table 9. Daily cooling power for the different system plants, 16 July.

\begin{tabular}{|c|c|c|c|c|}
\hline \multicolumn{5}{|c|}{$16^{\text {th }}$ July cooling power $[\mathrm{kW}]$} \\
\hline & \multirow[t]{2}{*}{ Existing plant } & \multirow[t]{2}{*}{ Fancoil $24 \mathrm{hrs}$} & \multicolumn{2}{|c|}{ Proposed plant } \\
\hline & & & CAV system & Radiant panels \\
\hline Brunelleschi Hall & 804 & 810 & 104 & 978 \\
\hline Banner Hall & 114 & 91 & 206 & 39 \\
\hline Captains Hall & 45 & 120 & 194 & 103 \\
\hline Fireplace Hall & 212 & 267 & 206 & 121 \\
\hline
\end{tabular}


Fireplace Hall

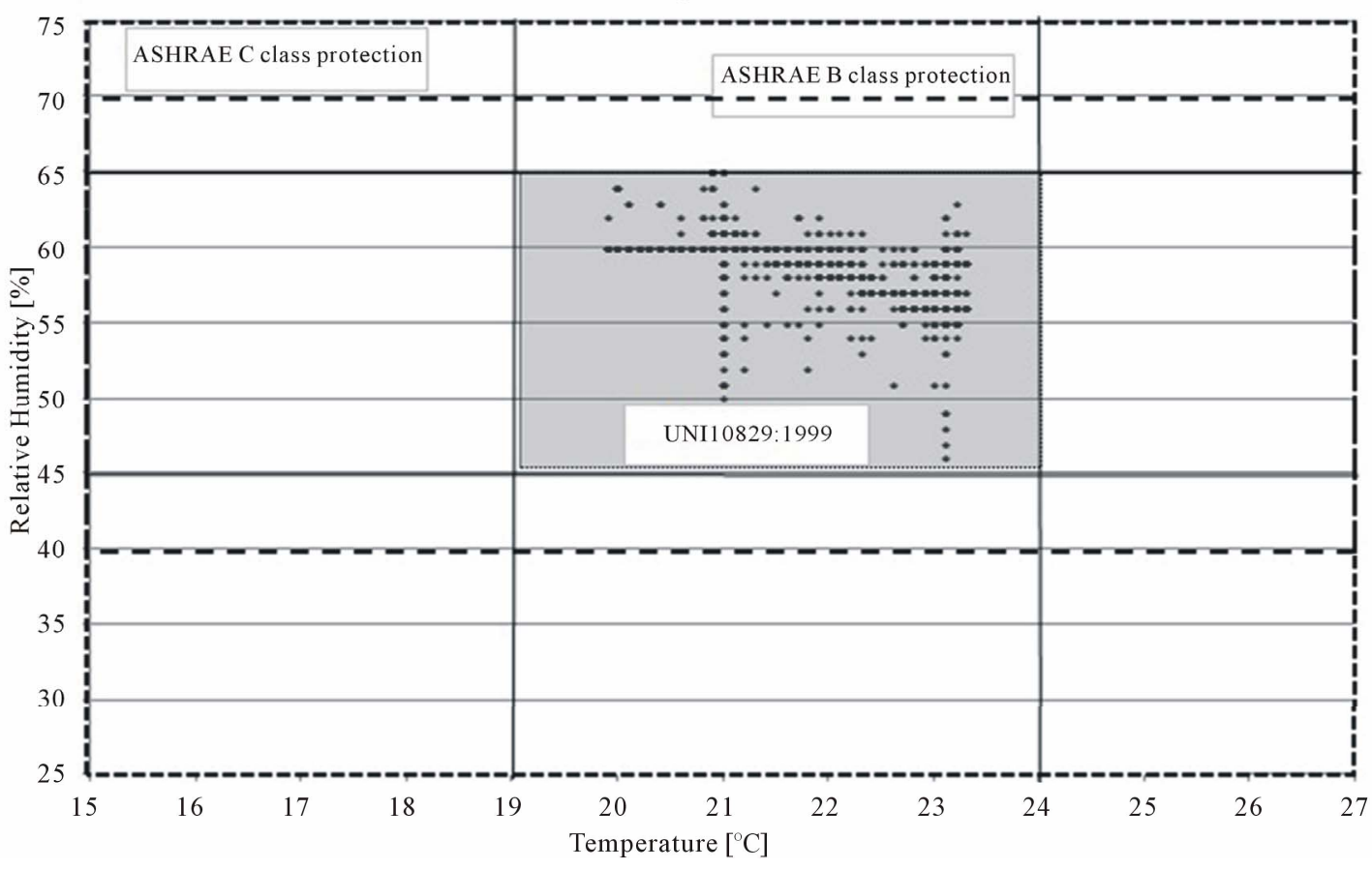

Figure 8. Transient simulation results on the yearly temperature and relative humidity values and the corresponding acceptability values range inside the Fireplace Hall obtained for the proposed plant system.

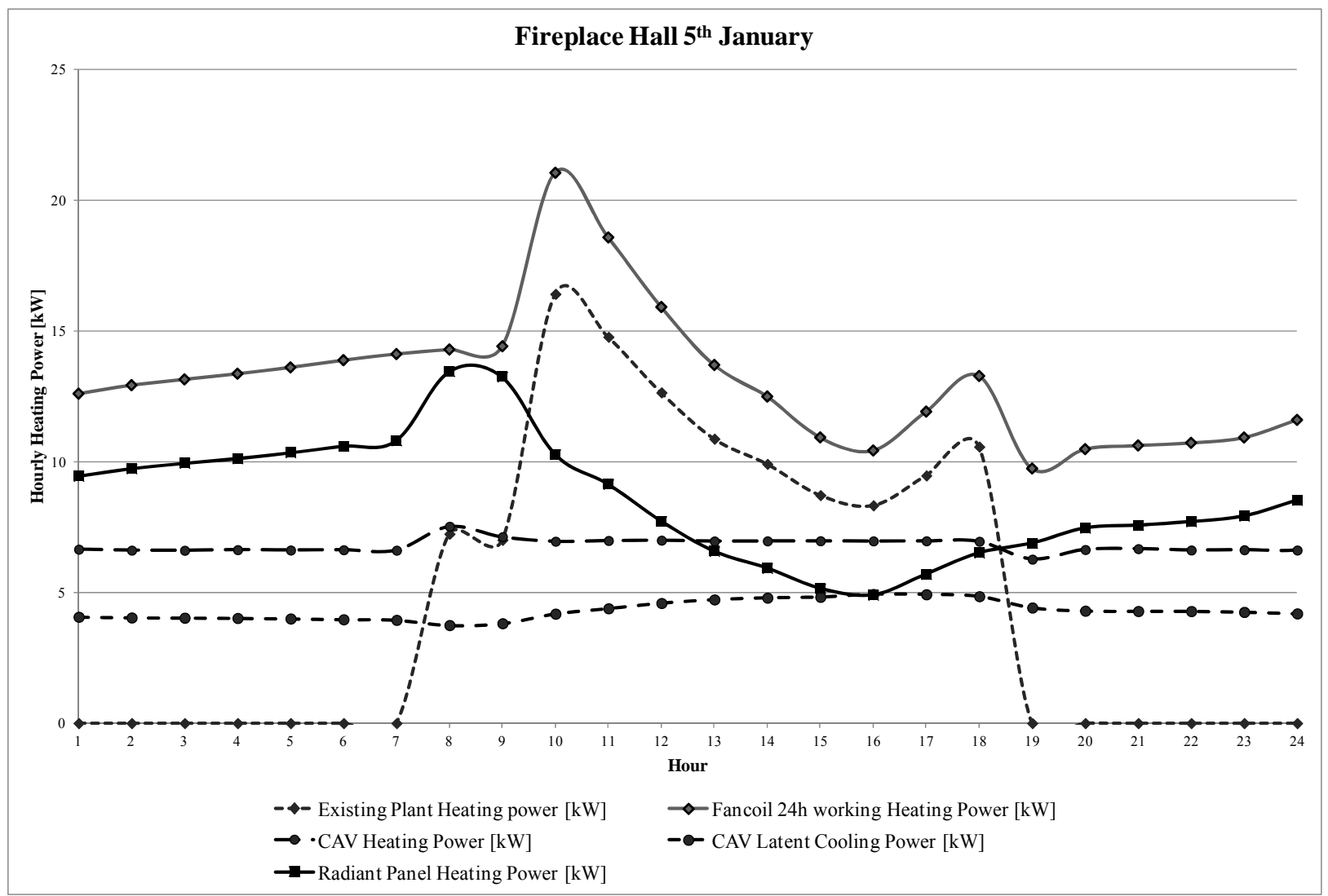

Figure 9. Transient simulation results comparison between the hourly heating power of the fancoils existing system, with $24 \mathrm{~h}$ working, and the proposed plant solution for the Fireplace Hall; 5 January. 
with particular attention to the " $C A V$ Latent Cooling Power" trend. In the summer and winter seasons, the plant performances are very similar for Fireplace Hall and Brunelleschi Hall, but not extendable to all the other halls. In the Banner Hall and Captains Hall the microclimate control system requires higher air flow rates treated (Table 7). For these halls the air flow rate required for ventilation is higher (Table 6), due to their reduced base areas and their lower heights, compared tothose of Brunelleschi and Camino Halls that present a double volume (Table 2). For the Banner Hall, Figures 11 and 12 show the comparison between the thermal powers required by the existing fancoils plant, considered in working conditions from 7:00 to 19:00 and during all the $24 \mathrm{hrs}$, and that required by the proposed plant solution. These figures show how the greater air flow rates, necessary for the Banner Hall, provide the highest cooling powers for air dehumidification both in the winter and summer seasons. Consequently, the power of the radiant panels system is reduced and is necessary only for the winter season. In the summer season, the CAV system is sufficient to control the indoor microclimatic conditions (Figure 11).

Transient simulations, carried out for the whole year for all the thermal zones, allowed the evaluation of an- nual energy consumption. Table 10 shows the comparison between the annual energy consumption for the different halls and for the different system plants considered. The annual energy consumption due to air treatment isparticularly influenced by the power required by cooling and post-heating plant systems. For most of the year, the supplied air to the halls must be dehumidified. Table $\mathbf{1 0}$ shows that thermal energy due to air dehumidification is very high. For the proposed plant this implies a total energy consumption for cooling and air treatment, twice that of the existing fancoil plant with 24 hours working conditions.

As an example, the Fireplace Hall presents energy consumption of $58.73 \mathrm{MW} / \mathrm{h}$ year, against $23 \mathrm{MW} / \mathrm{h}$ year for the fancoil system working 24 hours. But even if energy consumption is higher, the plant system proposed guarantees the protection and conservation of works of art at the indoor microclimatic conditions suggested by the standards, and also occupant and visitors comfort conditions.

\section{Conclusions}

The energy retrofitting and refurbishment of historicalbuildings is a complex question because usually in Italy these buildings are converted into museums and this

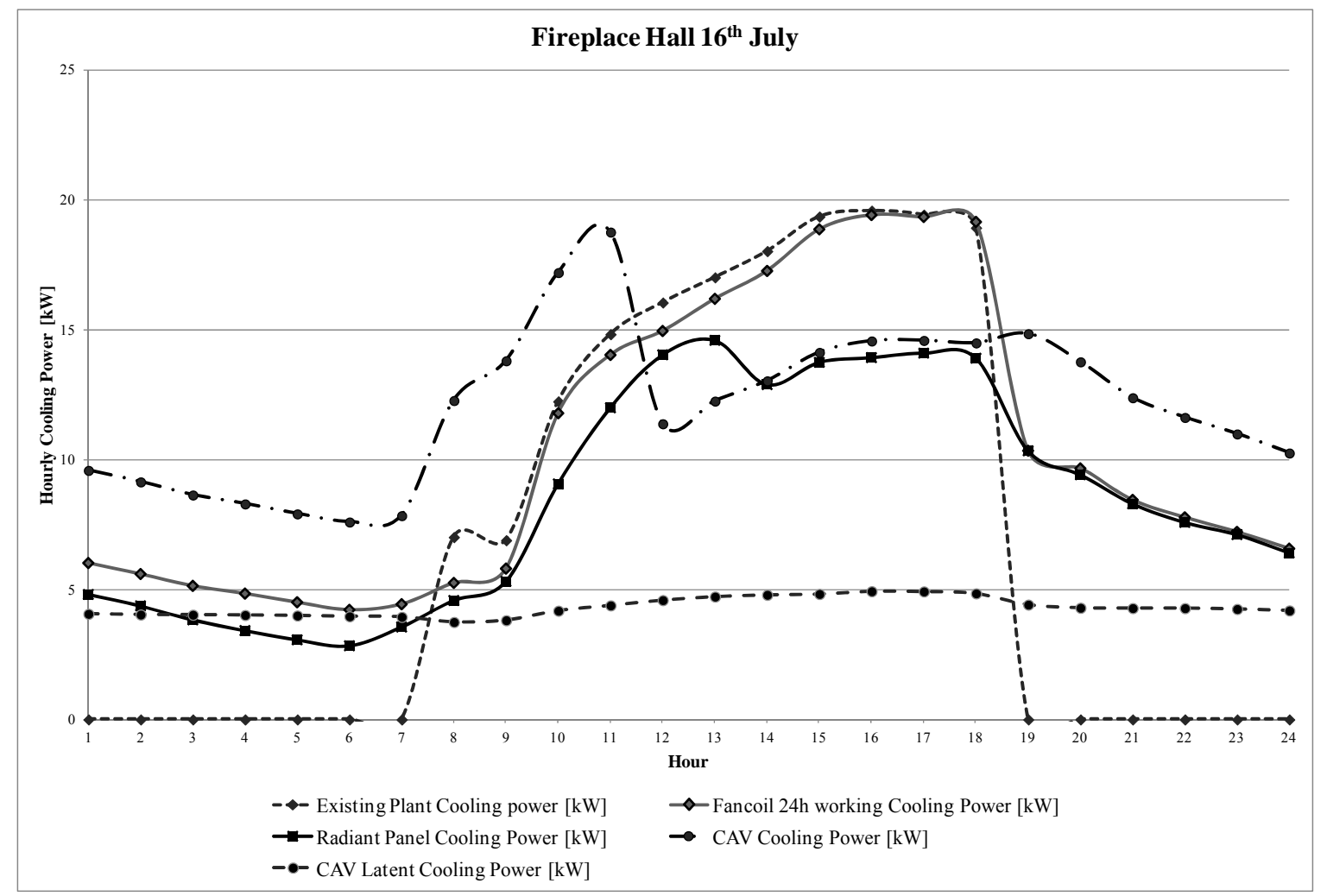

Figure 10. Transient simulation results comparison between the hourly cooling power of the fancoils existing system, with 24 h working, and the proposed plant solution for the Fireplace Hall; 16 July. 
Table 10. Annual thermal energy need.

\begin{tabular}{|c|c|c|c|c|c|c|c|c|c|c|c|}
\hline \multicolumn{12}{|c|}{ Annual Energy Need } \\
\hline & \multicolumn{2}{|c|}{ Existing Plant } & \multicolumn{2}{|c|}{ Fancoil 24 hrs } & \multicolumn{7}{|c|}{ Proposed Plant } \\
\hline & $\begin{array}{c}\text { Heating } \\
{[\mathrm{kWh} \text { year }]}\end{array}$ & $\begin{array}{c}\text { Cooling } \\
{[\mathrm{kWh} \text { year }]}\end{array}$ & $\begin{array}{c}\text { Heating } \\
{[\mathrm{kWh} \text { year }]}\end{array}$ & $\begin{array}{c}\text { Cooling } \\
{[\mathrm{kWh} \text { year }]}\end{array}$ & $\begin{array}{c}\text { CAV } \\
\text { Heating } \\
{[\mathrm{MW}]}\end{array}$ & $\begin{array}{c}\text { CAV } \\
\text { Cooling } \\
{[\mathrm{kWh} \text { year }]}\end{array}$ & $\begin{array}{c}\text { Radiant } \\
\text { Heating } \\
{[\mathrm{kWh} \text { year] }}\end{array}$ & $\begin{array}{c}\text { Radiant } \\
\text { Cooling } \\
{[\mathrm{kWh} \text { year }]}\end{array}$ & $\begin{array}{c}\text { Dehumidification } \\
\text { [kWh year }]\end{array}$ & $\begin{array}{c}\text { Total } \\
\text { CAV } \\
\text { Heating } \\
{[\mathrm{kWh} \text { year }]}\end{array}$ & $\begin{array}{c}\text { Total } \\
\text { CAV } \\
\text { Cooling } \\
{[\mathrm{kWh} \text { year }]}\end{array}$ \\
\hline $\begin{array}{l}\text { Brunelles } \\
\text { chi Hall }\end{array}$ & 27,430 & 51,019 & 55,166 & 96,143 & 73,203 & 42,527 & 77,333 & 83,348 & 40,846 & 114,048 & 83,372 \\
\hline $\begin{array}{c}\text { Banner } \\
\text { Hall }\end{array}$ & 4374 & 7203 & 8568 & 14,001 & 60,734 & 31,333 & 6645 & 0 & 30,600 & 91,334 & 61,933 \\
\hline $\begin{array}{l}\text { Captains } \\
\text { Hall }\end{array}$ & 3377 & 6172 & 10,403 & 12,116 & 56,816 & 27,745 & 5360 & 7479 & 28,249 & 85,065 & 55,993 \\
\hline $\begin{array}{c}\text { Fireplace } \\
\text { Hall }\end{array}$ & 9963 & 12,084 & 35,084 & 23,034 & 60,598 & 29,600 & 22,040 & 13,043 & 29,129 & 89,726 & 58,728 \\
\hline
\end{tabular}

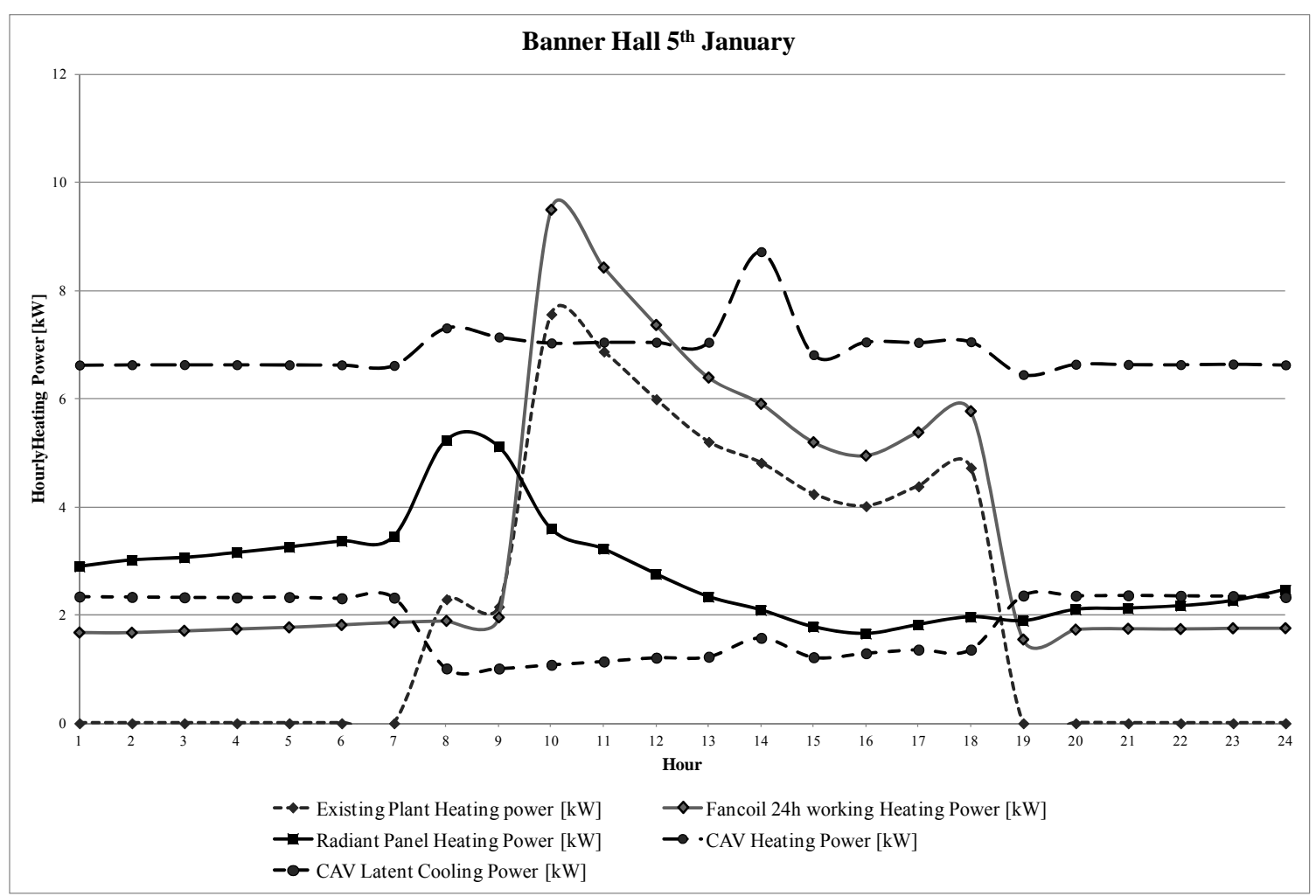

Figure 11. Transient simulation results comparison between the hourly heating power of the fancoils existing system, with 24 $\mathrm{h}$ working, and the proposed plant solution for the Banner Hall; 5 January.

causes the lack of space for plant allocation and integration with the architectural structures. Plant design proposals should start from the minimum incidence on the building structure and present conditions under which the "building system has become stable" following seasonal climatic variations. The proposed plant system for the studied Halls is based on the minimum impact and reversibility concept. It guarantees the conservation and maintenance conditions of their works of art, but also for the whole building of Palagio that is a work of art and a museum at the same time, and then thermal comfort for occupants and visitors. The sustainability of the proposed plant has to be understood in terms of reversibility (minor impact and major removable solutions) and energy sustainability that is rational energy utilization to guarantee, with the lower possible consumption, the previously mentioned requirements both for visitors/occupants and works of art.

The presented case study can be considered as an example of refurbishment and energy retrofitting of a historical building converted to museum where a movable and easy to maintain system plant could be recommended. 


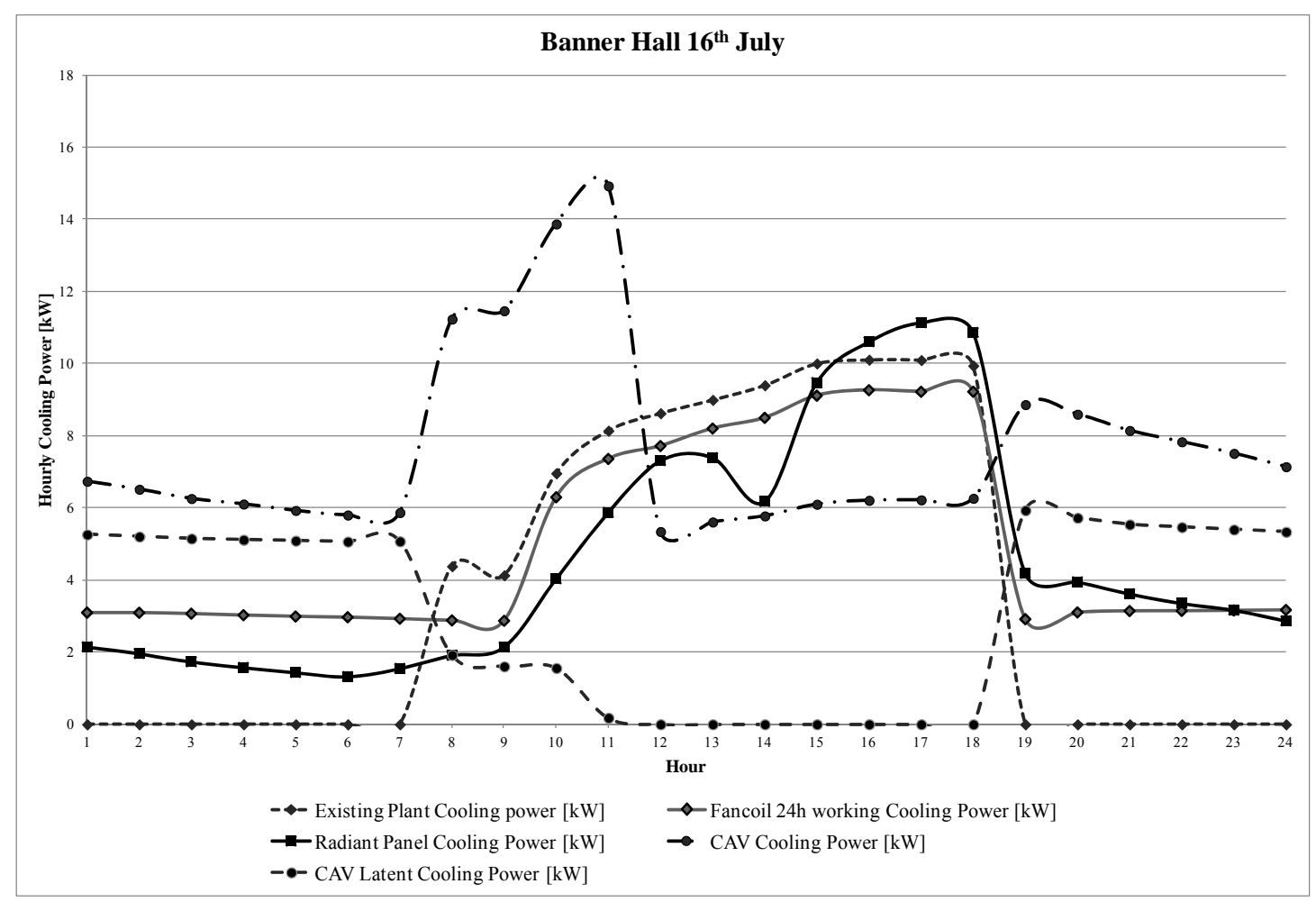

Figure 12. Transient simulation results comparison between the hourly cooling power of the fancoils existing system, with 24 $\mathrm{h}$ working, and the proposed plant solution for the Banner Hall; 16 July.

\section{Acknowledgements}

The authors thank all the staff of the Technical Offices of the Florence Municipality for the provided data and information, that was crucial for this research.

\section{REFERENCES}

[1] A. M. Papadopoulos, A. Avgelis and M. Santamouris, "Energy Study of a Medieval Tower Restored as a Museum," Energy and Buildings, Vol. 35, No. 9, 2003, pp. 951-961. doi:10.1016/S0378-7788(03)00025-2

[2] C. Del Curto and M. Fratelli, "Historical Building as Museums: Building and Artworks Preservation; Plans for Existing System Restoration and Integration," IL Prato, Vicenza, 2010.

[3] AICARR, "Tecnologie Impiantistiche per i Musei," Proceedings of Italian Congress, Roma, 6 May 2005.

[4] D. Del Curto, "Indoor Environment and Preservation," Nardini, Firenze, 2011.

[5] A. W. M. Van Schijndel, H. L. Schellen, J. L. Wijffelaars and K. Van Zundert, "Application of an Integrated Indoor Climate HVAC and Showcase Model for the Indoor Climate Performance of a Museum," Energy and Buildings, Vol. 40, No. 4,2008, pp. 647-653. doi:10.1016/j.enbuild.2007.04.021

[6] C. Balocco and G. Grazzini, "Plant Refurbishment in Historical Buildings Turned into Museum," Energy and Buildings, Vol. 39, No. 6, 2007, pp. 693-701. doi:10.1016/j.enbuild.2006.06.012
[7] Bentley Software, "TAS Building Simulator, 9.2.1.3 Version."

[8] ISO 6946:2007, "Building Components and Building Elements-Thermal Resistance and Thermal TransmittanceCalculation Method."

[9] Comitato Termotecnico Italiano, "CTI Standard Year of Tuscany-Italy Referring to UNI EN ISO 15927-4:2005 Hygrothermal Performance of Buildings. Calculation and Presentation of Climatic Data-Part 4: Hourly Data for Assessing the Annual Energy Use for Heating and Cooling."

[10] UNI EN 10339:1995, “Air-Conditioning Systems for Thermal Comfort in Buildings. General, Classification and Requirements. Offer, Order and Supply Specifications."

[11] UNI EN ISO 15265:2005, "Ergonomics of the Thermal Environment-Risk Assessment Strategy for the Prevention of Stress or Discomfort in Thermal Working Conditions."

[12] N. Rossi, "Manuale del Termotecnico," 3rd Edition, Hoepli, Milano, 2010.

[13] ASHRAE, "Handbook of Fundamentals, American Society of Heating," Refrigeration and Air-Conditioning Engineers, Inc., Atlanta, 1997.

[14] M. Gough, "A New Method for the Calculation of Heat Transfer in Walls and Roofs," CIB International Symposium on System Simulation in Buildings, Liege, 6-9 December 1982.

[15] L. A. Pipes, "Matrix Analysis of Heat Transfer Problems," Franklin Institute Journal, Vol. 263, No. 3, 1957, pp. 195- 
205. doi:10.1016/0016-0032(57)90927-4

[16] Italian Standards D.P.R. No.412:1993 and D.P.R. No.551: 1999, "Regolamento Recante Norme per la Progettazione, L'installazione, L'esercizio e la Manutenzione Degli Impianti Termici Degli Edifici ai fini del Contenimento dei Consumi di Energia."

[17] Italian Standard D.M. 10-05-2001, “Atto di Indirizzo sui Criteri Tecnico-Scientifici e Sugli Standard di Funzionamento e Sviluppo dei Musei."

[18] UNI EN 15757:2010, “Conservation of Cultural Property-Specifications for Temperature and Relative Humidity to Limit Climate-Induced Mechanical Damage in Organic Hygroscopic Materials."

[19] Italian Standard UNI 10829:1999, "Beni di Interesse Storico Artistico. Condizioni Ambientali di Conservazione.
Misurazione ed Analisi."

[20] ASHRAE, "Handbook: HVAC Applications," American Society of Heating, Refrigerating Air-Conditioning Engineers Inc., Atlanta, 2003.

[21] D. Camuffo, et al., "Church Heating and the Preservation of Cultural Heritage," Mondadori Electa, Milano, 2007.

[22] ASHRAE, "ASHRAE Handbook HVAC Systems and Equipment (SI)," American Society of Heating, Refrigerating Air-Conditioning Engineers, Inc., Atlanta, 2008.

[23] M. Vio, "Impianti Energeticamente Positivi," AICARR Journal, Vol. 7, No. 1, 2011, pp. 22-31. 


\section{Appendix}

In this Appendix the main steps of the method are provided. The inputs are as following: hourly temperature of the neighbouring thermal zones including the hourly external air temperature and hourly relative humidity, total hourly thermal gains inside the studied zone (heat produced by occupants and equipment), heat flux due to solar radiation coming through the windows, thickness, thermal conductivity, density and specific heat capacity of each layer of each wall surrounding the studied thermal zone, air flow rates due to infiltrations, natural and mechanical ventilation and air exchanges between thermal zones. The thermal state of each building component, assuming linear and mono-dimensional heat flow distribution, is described using normal co-ordinate variables that define the temperature decomposition and thermal flux distributions. The eigenfunctions, that are linear solution of the heat exchange differential equations, are updated at each time increment, and used combined with the solutions of precedent time-step.

The software starts by evaluating the energy balance of each zone for each hour, as following:

$$
\begin{aligned}
& Q^{\text {plantS }}+Q^{\text {sol }}+Q^{\text {light }}+Q^{\text {occ } S}+Q^{\text {equS }}+Q^{\text {inf/vent }} \\
& +Q^{B H T}+Q^{A M}=0
\end{aligned}
$$

where the different terms are:

$Q^{\text {plantS }}$ Plant: total power input from the plant [W];

$Q^{\text {sol }}$, Solar gains: sum of the surface solar gains for all the surfaces facing to the zone [W];

$Q^{\text {light }}$ Lighting gain: power input from lights [W];

$Q^{\text {occS }}$ Occupancy gain: sensible power input from occupants [W];

$Q^{\text {equS }}$ Equipment gain: sensible power input from equipment [W];

$Q^{\text {inf/vent }}$ Infiltration/ventilation heat gain: heat gained (or lost, if negative) by the zone due to the air flow exchanges, $m_{0 Z}[\mathrm{~kg} / \mathrm{h}]$, between the zone and the external ambient [W];

$$
\begin{aligned}
Q^{\text {inf } / \text { vent }}= & Q^{\text {inf }}+Q^{\text {vent }}+m_{0 Z} c_{p}\left(T_{0}^{\text {air }}-T^{\text {air }}\right) \\
Q^{\text {inf } / \text { vent }}= & m_{\text {inf }} c_{p}\left(T_{0}^{\text {air }}-T^{\text {air }}\right)+m_{\text {vent }} c_{p}\left(T_{0}^{\text {air }}-T^{\text {air }}\right)( \\
& +m_{0 Z} c_{p}\left(T_{0}^{\text {air }}-T^{\text {air }}\right)
\end{aligned}
$$

where:

$T_{0}^{\text {air }}$ : Outside air temperature $[\mathrm{K}]$;

$T^{\text {air }}$ : Zone air temperature $[\mathrm{K}]$;

$m_{\text {inf: }}$ Infiltration air mass flow rate $[\mathrm{kg} / \mathrm{s}]$;

$m_{\text {vent }}$ : Ventilation air mass flow rate $[\mathrm{kg} / \mathrm{s}]$;

$m_{0 Z}$ : Mass flow rate from outside to the zone $[\mathrm{kg} / \mathrm{s}]$;

$Q^{A M}$ air internal movement which represents heat gained via specified inter-zone air movement flows, $m_{S Z}[\mathrm{~kg} / \mathrm{s}]$, and via air movement through apertures linked to other zones:

$$
Q^{A M}=-\sum_{s=1}^{Z} m_{S Z} c_{p}\left(T_{0}^{a i r}-T^{a i r}\right)
$$

$Q^{B H T}$ Building heat transfer: the sum of the conduction heat transfer from building components $\left(q_{i}^{\text {cond }}\right)$, the convective heat transfer $\left(q^{\text {conv }}\right)$ and the heat released into the zone temporarily stored in the air $Q^{\text {air }}[\mathrm{W}]$;

$$
\begin{aligned}
Q^{B H T} & =-Q \operatorname{cond}-Q \operatorname{conv}-Q^{\text {air }} \\
& =-\sum_{i} A \cdot\left(q_{i}^{\text {cond }}+q^{\text {conv }}\right)-Q^{\text {air }}
\end{aligned}
$$

The conduction heat flux into the building component, $q^{\text {cond }}[\mathrm{W}]$, is calculated by the, effective building component surface $A\left[\mathrm{~m}^{2}\right]$, the average value between the internal and external surfaces, provided by the $3 \mathrm{D}$ model. Then:

$$
\begin{aligned}
q^{\text {cond }} & =A W^{\text {cond }}=A \cdot\left(X^{0} T^{\text {int }}+X^{1}\left\langle T^{\text {int }}\right\rangle\right. \\
& \left.-Y^{0} T^{e x t}-Y^{1}\left\langle T^{e x t}\right\rangle+\sum_{n=1}^{N} V_{n}^{\text {int }} v_{n}\right) \\
q^{\text {cond }} & =A \cdot X^{0} T^{\text {int }}-A \cdot Y^{0} T^{\text {ext }}+q^{\text {hist_cond }}
\end{aligned}
$$

where $q^{\text {hist_cond }}$ is the sum of all the terms evaluated from results obtained from the previous time-steps.

The dynamic evaluation of the heat fluxes exchanged between two surfaces of a building component, $W^{\text {cond,int }}$, is calculated using the following equations:

$$
\begin{aligned}
W^{\text {cond, int }}= & X^{0} T^{\text {int }}+X^{1}\left\langle T^{\text {int }}\right\rangle-Y^{0} T^{\text {ext }} \\
& -Y^{1}\left\langle T^{\text {ext }}\right\rangle+\sum_{n=1}^{N} V_{n}^{\text {int }} v_{n}
\end{aligned}
$$

The normal coordinate variables $v_{n}$ are updated at each time step using the previous time-step surface temperatures:

$$
v_{n}=\delta_{n}^{\text {int }}\left\langle\left\langle T^{\text {int }}\right\rangle\right\rangle+\delta_{n}^{\text {ext }}\left\langle\left\langle T^{\text {ext }}\right\rangle\right\rangle+\eta_{n}\left\langle v_{n}\right\rangle,(n=1,2, \cdots, N)
$$

where $\langle\langle\chi\rangle\rangle$ (where $\chi$ is any variable) denotes the value of the previously two time-steps; $\delta_{n}^{\text {int }} \delta_{n}^{\text {ext }} \quad \eta_{n}$ are constants.

For each time step of the simulation, the surface temperature evolution and distribution during time, and the normal coordinate variables are initialized to a steady state condition. As the simulation proceeds, Equations (4) and (5) are used at each time-step, to establish the linear relationships between the obtained temperatures values of the component surfaces and the heat fluxes. These relationships are incorporated in the matrix equations representing the total heat balance for each thermal zone.

The convective heat flow, $q^{\text {conv }}[\mathrm{W}]$, from the air to the surface is calculated for an inner surface referring to [4], as follows: 


$$
\begin{gathered}
q^{\text {conv, int }}=A \cdot W^{\text {conv }, \text { int }} \\
q^{\text {conv, int }}=A \cdot h^{\text {int }}\left(T^{\text {air }}-T^{\text {int }}\right) \\
h^{\text {int }}=\left\{\left[\left(\mid \frac{\left|T^{\text {air }}-T^{i n t}\right|}{L}\right)^{1 / 4}\right]^{1 / 6}+\left[b\left(\left|T^{\text {air }}-T^{i n t}\right|\right)\right]^{6}\right\}^{1 / 6}
\end{gathered}
$$

$Q^{\text {air }}$ is calculated with:

$$
Q^{a i r}=\frac{\left(\rho^{a i r} \cdot V \cdot c_{p}\right) \cdot\left(T^{a i r}-\left\langle T^{a i r}\right\rangle\right)}{\Delta}
$$

where:

$W^{\text {cond }}$ : Conduction heat transfer $\left[\mathrm{W} / \mathrm{m}^{2}\right]$;

$h^{\text {int }}$ : Convective heat transfer coefficient $\left[\mathrm{W} / \mathrm{m}^{2} \mathrm{~K}\right]$;

$T^{\text {in }}$ : Internal surface temperature $[\mathrm{K}]$;

$T^{\text {ext }}$ : External surface temperature $[\mathrm{K}]$;

$T^{\text {air }}$ : Air zone temperature $[\mathrm{K}]$;

$L$ : Characteristic length [m] of the heat transfer surface (height of the studied component or hydraulic diameter);

$a, b$ : Numerical coefficient;

$\rho^{\text {air }}:$ Air density $\left[\mathrm{kg} / \mathrm{m}^{3}\right]$;

$V$ : Volume of the zone $\left[\mathrm{m}^{3}\right]$;

$c_{p}$ : Air specific heat capacity at constant pressure, $[\mathrm{J} / \mathrm{kg}$ $\mathrm{K}]$;

$\Delta$ : Time-step;

$\langle\chi\rangle$ : (where $\chi$ is any variable) parameter value at the previous time-step;

$X^{0}, X^{1}, Y^{0}, Y^{1}, Z^{0}, Z^{1}$ response factors $\left[\mathrm{W} / \mathrm{m}^{2} \mathrm{~K}\right]$ : constants which characterize the wall response to the last surface temperature values distribution;

$V_{n}(n=1,2, \cdots, N)$ set of normal coordinate variables (with dimensions of the heat flux $\left[\mathrm{W} / \mathrm{m}^{2}\right]$ ) which describes the wall thermal condition, at each time-step connected to a set of eigenfunctions;

$V_{n}^{\text {int }} V_{n}^{\text {ext }}(n=1,2, \cdots, N)$ dimensionless constants which characterize the relationship between the surface fluxes and the normal coordinate variables.

The indoor air conditions are evaluated solving the Energy Balance, starting from the Room Response Characteristic evaluation (Equation (A11)). Solving the Energy Balance $Q^{\text {plantS }}$, the total heat power of the plant can be obtained using the $2 M+2$ linear equations for the $2 M$ +2 unknown temperatures, where $M$ is the number of the thermal zone surfaces.

The linear equations are solved using an efficient matrix technique, to establish as follows:

$T_{0}$ : The zone air temperature, with no plant input $[\mathrm{K}]$;

$\Theta^{\text {htg10000}}$ : The air temperature increase, resulting from an increase of $10 \mathrm{~kW}$ in the plant input for the heating condition $[\mathrm{K}]$;
$\Theta^{c l g 10000}$ : The air temperature increase, resulting from an increase of $10 \mathrm{~kW}$ in the plant input for the cooling condition $[\mathrm{K}]$;

The Room Response Characteristic provides a relationship between $T^{0}$, the zone air temperature, and $Q^{\text {plant } S}$ the plant input, for each time-step, as following:

$$
\begin{array}{ll}
T^{\text {air }}=T^{0}+\frac{\Theta^{\text {htg } 10000} Q^{\text {plantS }}}{10000} & \left(Q^{\text {plantS }}>0\right) \\
T^{\text {air }}=T^{0}+\frac{\Theta^{\text {htg } 10000} Q^{\text {plantS }}}{10000} \quad\left(Q^{\text {plantS }}<0\right)
\end{array}
$$

The air specific humidity, $x\left[\mathrm{~kg}_{\mathrm{v}} / \mathrm{kg}_{\mathrm{a}}\right.$, is defined as the mass of water vapor in the air per unit mass of dry air. The input of the quantity of water vapor in the studied thermal zone $(\mathrm{kg} / \mathrm{s})$ produce an increase $(\mathrm{d} x / \mathrm{d} t[\mathrm{~kg} / \mathrm{kg} \cdot \mathrm{s}]$ of these values, as following:

$$
w^{\text {air }}=\frac{\left(\rho^{\text {air }} V\right) \cdot(x-\langle x\rangle)}{\Delta}
$$

The humidity controls add or remove humidity from each thermal zone to maintain the relative humidity inside the set-point range values; taking into account the humidity rate, $w[\mathrm{~kg} / \mathrm{s}]$, the Latent Load, $Q^{\text {plantL }}[\mathrm{W}]$, is calculated as follows:

$$
\begin{aligned}
& \left(\frac{\rho^{\text {air }} V}{\Delta}+m^{\text {inf }}+m^{\text {vent }}+\sum_{S=0}^{Z} m_{S Z}\right) x \\
& =\left(\frac{\rho^{\text {air }} V}{\Delta}\langle x\rangle+\left(m^{\text {inf }}+m^{\text {vent }}\right) \cdot x_{0}\right. \\
& \left.+\sum_{S=0}^{Z} m_{S Z} x_{s}+w^{\text {gains }}+w^{\text {plant }}\right)
\end{aligned}
$$

where $x_{0}$ is the humidity ratio of outdoor air.

The Equation (A13) is solved assuming that there is no latent heat control of the plant system. Therefore, the indoor humidity ratio is checked in comparison with the humidity ratio set-point. If the obtained result respects the set-point humidity values, the latent load $Q^{\text {plant } L}$ has to be set to zero and no further analysis will be done. If the humidity ratio obtained value does not correspond to the imposed limits, it will be set to the limit value and the corresponding plant input, $W^{\text {plant }}$, will be calculated from Equation (A13) as follows:

$$
Q^{\text {plantL }}=L \cdot W^{\text {plant }}
$$

where $L$ is the latent heat of evaporation of water, 2450 $\mathrm{kJ} / \mathrm{kg}$. 